(c) Group of authors, 2018

UDC 616-006:576.385.5:611.441(574)

DOI - https://doi.org/10.14300/mnnc.2018.13079

ISSN - 2073-8137

\title{
PREVALENCE OF MUTANT BRAFV600E IN THE PAPILLARY THYROID CARCINOMA IN PATIENTS FROM KAZAKHSTAN AND ITS CORRELATION WITH CLINICAL-MORPHOLOGICAL TUMOR CHARACTERISTIC
}

Tlegenov A. Sh. ${ }^{1}$, Abylaiuly Zh. ${ }^{1}$, Adilbay D. G. ${ }^{2}$, Yeleubaeva Sh. B. ${ }^{2}$, Adilbayev G. B. ${ }^{2}$, Satbaeva E. B. ${ }^{2}$, Bolshakova S. V. ${ }^{1}$

${ }^{1}$ Kazakh National Medical University named after S. D. Asfendiyarov, Almaty, Kazakhstan

2 Scientific Research Institute of Oncology and Radiology, Almaty, Kazakhstan

\section{РАСПРОСТРАНЕННОСТЬ МУТАНТНОГО ВRАFУ600Е В ПАПИММЯРНОМ РАКЕ ЩИТОВИАНОЙ ЖЕАЕЗЫ У ПАЦИЕНТОВ ИЗ КАЗАХСТАНА И ЕГО СВЯЗЬ С КАИНИКО-МОРФОАОГИЧЕСКИМИ ХАРАКТЕРИСТИКАМИ ОПУХОАИ}

\author{
А. Ш. Тлегенов ${ }^{1}$, Ж. Абылайулы ${ }^{1}$, А. Г. ААилбай ${ }^{2}$, Ж. Б. Елеубаева ${ }^{2}$, \\ Г. Б. ААильбаев ${ }^{2}$, Э. Б. Сатбаева ${ }^{2}$, С. В. Большакова ${ }^{1}$ \\ ${ }^{1}$ Казахский национальный меАицинский университет им. С. А. АсффенАиярова, \\ Алматы, Казахстан \\ 2 КазахсКий научно-исслеАовательсКий институт онкологиИ и РаАиологии, \\ А^маты, Казахстан
}

The BRAF ${ }^{\mathrm{V} 600 \mathrm{E}}$ mutation is the most frequent somatic oncogenic event in adult patients with papillary thyroid carcinoma (PTC). This work set out to determine the prevalence of mutant BRAF and its correlations with clinical-morphological characteristics of PTC, and to examine feasibility of detection of BRAF ${ }^{\mathrm{V} 600 \mathrm{E}}$ in fine-needle aspiration biopsy material in patients from Kazakhstan. A total of 92 consequent patients diagnosed and treated for PTC from January 2016 to July 2017 were enrolled. Serial tissue sections of formalin-fixed paraffin embedded tissues were stained with hematoxylin and eosin, and immunohistochemically with monoclonal antibodies specific to the BRAF ${ }^{\mathrm{V} 600 \mathrm{E}}$ protein. Positive immunohistochemical reaction was registered in $67.4 \%$ of cases. biopsy

Keywords: papillary thyroid carcinoma, BRAF mutation, tumor morphology, tumor aggressiveness, fine-needle aspiration

Мутация BRAFV600E является наиболее частым соматическим онкогенным событием в папиллярном раке щитовидной железы (ПРЩЖ) у взрослых пациентов. В настоящей работе определялась частота встречаемости мутантного BRAF в ПРЩЖ у пациентов из Казахстана, анализ взаимосвязи мутации с клинико-морфологическими характеристиками опухоли и демонстрация возможности практического выявления BRAFV600E в материале тонкоигольной аспирационной биопсии узлов ЩЖ. В исследование были включены 92 пациента, лечившихся по поводу ПРЩЖ с января 2016 по июль 2017 г. Серийные срезы тканей из парафиновых блоков окрашивали гематоксилин-эозином и иммуногистохимическим методом с использованием моноклональных антител, специфичных к мутантному белку $\mathrm{BRAF}^{\mathrm{V} 600 \mathrm{E}}$. Положительное иммуногистохимическое окрашивание было зарегистрировано в 67,4 \% случаев.

Ключевые слова: папиллярный рак щитовидной железы, мутация BRAF, морфология опухоли, агрессивность опухоли, тонкоигольная аспирационная биопсия

For citation: Tlegenov A. Sh., Abylaiuly Zh., Adilbay D. G., Yeleubaeva Sh. B., Adilbayev G. B., Satbaeva E. B., Bolshakova S. V. PREVALENCE OF MUTANT BRAF ${ }^{V 600 E}$ IN THE PAPILLARY THYROID CARCINOMA IN PATIENTS FROM KAZAKHSTAN AND ITS CORRELATION WITH CLINICAL-MORPHOLOGICAL TUMOR CHARACTERISTIC. Medical news of North Caucasus. 2018;13(3):468-473. DOI - https://doi.org/10.14300/mnnc.2018.13079

Для цитирования: Тлегенов А. Ш., Абылайулы Ж., Адилбай Д. Г., Елеубаева Ж. Б., Адильбаев Г. Б., Сатбаева Э. Б., БольшакОВа С. В. РАСПРОСТРАНЕННОСТЬ МУТАНТНОГО ВRАFV600Е В ПАПИЛЛЯРНОМ РАКЕ ЩИТОВИДНОЙ ЖЕЛЕЗЫ У ПАЦИЕНТОВ ИЗ КАЗАХСТАНА И ЕГО СВЯЗЬ С КЛИНИКО-МОРФОЛОГИЧЕСКИМИ ХАРАКТЕРИСТИКАМИ ОПУХОЛИ. Медицинский вестник Северного Кавказа. 2018;13(3):468-473. DOI - https://doi.org/10.14300/mnnc.2018.13079 
AUC - Area Under Curve

ddPCR - droplet digital Polymerase Chain Reaction

KSRIOR - Kazakh Scientific Research Institute of Oncology and Radiology

\author{
OR - Odds Ratios \\ PTC - Papillary Thyroid Carcinoma \\ WHO - World Health Organization
}

T hyroid cancer is the most common malignancy of the endocrine system [1], accounting for about $1-1.5 \%$ of all primary human cancers [2]. Among all types of thyroid cancer, papillary thyroid carcinoma (PTC) is the most frequent being diagnosed in $65-90 \%$ of cases with an annual increase in the incidence in most countries over the world [3].

Over the past two decades, a significant progress has been observed in understanding the molecular mechanisms of PTC. The most detailed study of 496 PTC was performed in the frame of The Cancer Genome Atlas in 2014 [4]. Somatic point mutations of the BRAF gene (almost always BRAF $^{\mathrm{V} 600 \mathrm{E}}$ in exon 15) were found in $62 \%$ those in the (codons 12,13 and 61 ) of the RAS familygenes in $13 \%$, and gene rearrangements in $15 \%$ of cases. In a large-scale meta-analysis that combined 6372 patients, the presence of a BRAF mutation was recorded in $51 \%$ of tumors. [5]. These data convincingly indicate that BRAFV600E is the most frequent oncogenic event in the PTC. An important circumstance is also the high specificity of BRAFV600E to PTC: it is not detected in any type of benign thyroid nodule or in follicular thyroid carcinoma.

The frequency of BRAF ${ }^{\mathrm{V} 600 \mathrm{E}}$ appears to vary in different ethnic groups of PTC patients. In different countries, the presence of a mutant gene was found in 25-90\% of tumors. In some cases, controversies could be seen even in the studies from the same country. Probably, these inconsistencies can at least partly be explained by the difference in the methods of detection the mutation (usually, molecular), interpretation of raw data, approaches to the selection of patient groups. In addition, the influence of the genetic background and dietary factors cannot be ruled out. The highest mutational rate, $90 \%$, was detected in PTC in adult Korean patients. [6]. In patients from European countries and North America, BRAF ${ }^{\mathrm{V} 600 \mathrm{E}}$ in 40$60 \%$ of tumors [7]. In patients from Russia, the frequency of BRAF ${ }^{\mathrm{V} 600 \mathrm{E}}$ was $60-65 \%$ [8].

The correlation of BRAF ${ }^{\mathrm{V} 600 \mathrm{E}}$ with the clinical and morphological characteristics of PTC was addressed in a number of studies. The results are quite different between the reports, which are probably due to both the above reasons and the possible particularities of morphological diagnostic systems characteristic for different schools and countries. Using meta-analysis, a statistically significant association of the BRAF ${ }^{\mathrm{V} 600 \mathrm{E}}$ mutation was found with the presence of regional metastasis, higher clinical stage of the tumor, larger tumor size, absence of a tumor capsule, the classical papillary architecture and tall-cell variant of PTC [5]

The prognostic value of BRAF ${ }^{\mathrm{V} 600 \mathrm{E}}$ in PTC was also investigated, and also with equivocal conclusions [9].

For the Republic of Kazakhstan, located between the European and Asian countries, the problem of thyroid cancer is very important. In Kazakhstan, about $60 \%$ of the territory where the main population resides, is characterized by iodine deficiency of varying degrees. In some regions there are uranium mining industries, and the north-eastern regions of the countrywere in vicinity to the Semipalatinsk nuclear test site. These factors are unfavorable and may potentially increase the risk for thyroid cancer.

No systematic study of the mutation of the BRAF mutation in PTC has been performed in Kazakhstan before, and relevant data is currently not available. In this study, using immunohistochemical staining, we determined the prevalence of mutant BRAF and its relationship to the clinical and morphological features of PTC in patients from Kazakhstan treated at the leading oncological institute of the country.

Material and Methods. The study included 92 consecutive patients with PTC ( 84 women and 8 men, mean age at the time of surgery $-45.8 \pm 15.1$ years, range 14-80 years) who received treatment, including surgery, at the Kazakh Scientific Research Institute of Oncology and Radiology (KSRIOR) from January 2016 to July 2017. Clinical-morphological characteristics and paraffin blocks obtained, from the database and the archive of Department of pathology and anatomy of the institute. The diagnosis of the PTC was independently confirmed by two pathologists. In this work, stratification by ethnic groups was not performed, since we aimed at determining the prevalence of mutations in PTCpatients in the population of Kazakhstan.The study was approved by the Ethical Committee of KSRIOR.

In addition to the international histological classification of PTC according to the WHO criteria [10], for the purposes of this study, tumors were further characterized by a predominant structural component (papillary, follicular or solid, when one of the structures comprised $>50 \%$ of the tumor tissue in a section). Since in many cases the tumors were represented by coexisting structures, occurrence those was also recorded. We also analyzed oxyphilic cell metaplasia, and concomitant thyroiditis and nodular thyroid disease.

Serialhistological4 $\mu \mathrm{m}$ sections were stained with hematoxylin and eosin, and immunohistochemicallys for the mutant BRAF. For the latter, the protocol described earlier was used [11]. After standard dewaxing, rehydration and washing procedures, an antigendemasking treatment was performed by autoclaving sections at $120{ }^{\circ} \mathrm{C}$ for $20 \mathrm{~min}$ in CC1 buffer (Ventana Medical Systems) followed by rinsing with distilled water. Blocking of endogenous peroxidase activity, as well as all subsequent steps (exceptfor the primary antibody), was performed using Novolink Polymer Detection System kit components (Leica Biosystems Newcastle Ltd., RE7140-K). Slides were incubated in a humid chamber with anti-BRAF ${ }^{\mathrm{V} 600 \mathrm{E}}$ (VE1) monoclonal antibodies diluted 1:100 in Antibody Diluent $V$ solution (catalog numbers E19290 and ADV-060 respectively, both from Spring Bioscience reagents). Further steps were performed in accordance with the recommendations of the Novolinkkit manufacturer, including $D A B$ staining and staining of the nuclei with hematoxylin at the end of the procedure. After dehydration and xylene clearing, sections were mountedin a synthetic polymer medium.

The results of immunohistochemical detection mutant BRAF were collectively evaluated and considered positive when an intense brown cytoplasmic staining of epithelial tumor cells was observed. A consensus opinion was reached in all cases.

Statistical analysis was performed using the IBM SPSS Statistics package (version 24). Univariateanalysis included exact Fisher test (or its extension), or a CochranArmitage trend test for nominal variable, and a nonparametric Mann-Whitney test for quantitative variables. Multivariate logistic regression analysis was performed to determine clinical and morphological parameters 
independently related to the mutational status of BRAF. The value of $p<0.05$ was considered to indicate a possible statistical significance.

For the droplet digital PCR (ddPCR), needle wash out material was collected after a fine needle aspiration biopsy of the thyroid nodules under ultrasound guidance. DNA was extracted using the proteinase Kphenol-chloroform extraction and ethanol precipitation protocol. The ddPCR protocol and reagents were kindly provided by Dr. M. Matsuse (Nagasaki University, Japan) and is available upon request. The analysis was performed using a QX200 Droplet Digital PCR System (Bio-Rad, USA).

Results and Discussion. Demographic data of patients and pathomorphological characteristics of examined tumors, are shown in Table 1. The presence of mutant BRAF (BRAF+) was detected in $62(67.4 \%)$ cases. The frequency of mutation in the Kazakh population in our study is consistent with that in adult patients from East Asia and Europe, and is close to that of $62 \%$ in the Atlas of the Cancer Genome [4]. Figure 1 demonstrates the examples of positive and negative immunohistochemical staining for mutant BRAF.

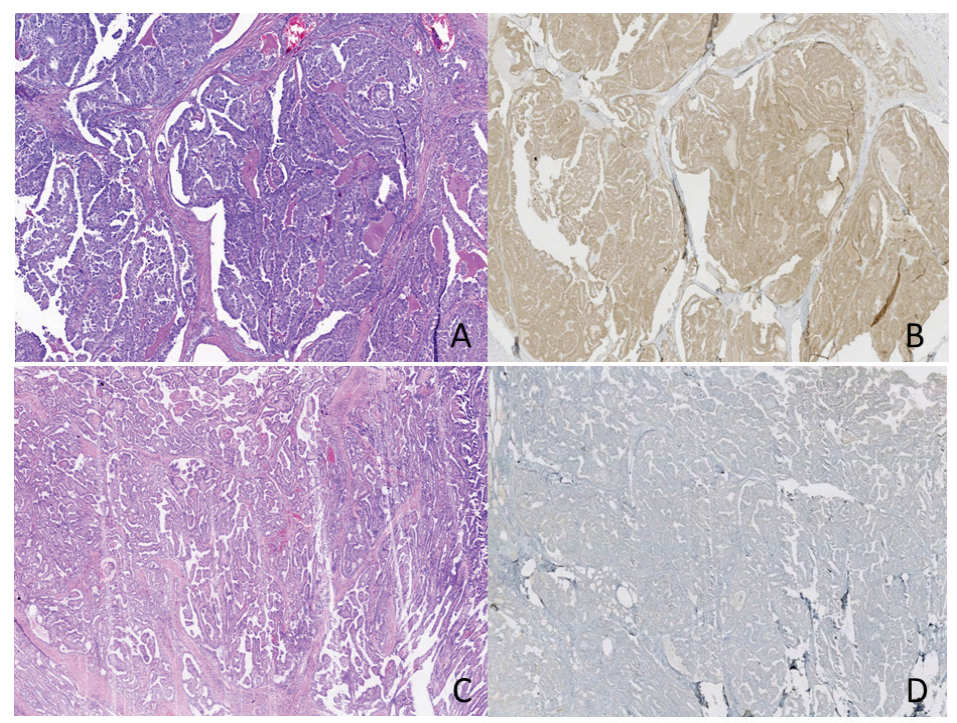

Fig. 1. Immunohistochemical detection of mutant BRAF in PTC: A - Classical papillary PTC stained with hematoxylin-eosin; B - positive immunohistochemical staining of tumor epithelial cells for mutant BRAF. A and B - serial sections; C - Classicalpapillary PTC. Stained with hematoxylin-eosin; D - negative immunohistochemical staining for mutanty BRAF. $B$ and $D-$ serial sections. Magnification: $A-D-x 100$

Table 1

Clinical and morphological characteristics of the PTC

\begin{tabular}{|l|c|c|c|}
\hline \multicolumn{1}{|c|}{ Parameters } & $\begin{array}{c}\text { BRAF- } \\
\mathrm{N}=30\end{array}$ & $\begin{array}{c}\mathrm{BRAF}+ \\
\mathrm{N}=62\end{array}$ & $\mathrm{p}$ \\
\hline Sex, F/M (\%) & $5 / 25(16.7 \%)$ & $6 / 56(9.7 \%)$ & 0.330 \\
\hline $\begin{array}{l}\text { Age at the time of surgery, } \\
\text { mean } \pm \text { SD, years (interval) }\end{array}$ & $\begin{array}{c}36.7 \pm 12.9 \\
(14-59)\end{array}$ & $\begin{array}{c}50.2 \pm 14.2 \\
(21-80)\end{array}$ & $7.352 \mathrm{E}-05$ \\
\hline $\begin{array}{l}\text { Tumor size, mean } \pm \text { SD, cm } \\
\text { (interval, full years) }\end{array}$ & $\begin{array}{c}1.8 \pm 0.8 \\
(0.25-3.5)\end{array}$ & $\begin{array}{c}1.8 \pm 0.9 \\
(0.5-4.0)\end{array}$ & 0.758 \\
\hline Tumor size subgroups: & & & 0.065 \\
\hline$\leq 1 \mathrm{~cm}$, microcarcinoma, $\%)$ & $7(23.3 \%)$ & $26(41.9 \%)$ & 0.106 \\
\hline $1.1-2.0$ cm (\%) & $15(50.0 \%)$ & $16(25.8 \%)$ & 0.033 \\
\hline$>2.1$ cm (\%) & $8(26.7 \%)$ & $20(32.3 \%)$ & 0.637 \\
\hline pT category: & & & 0.544 \\
\hline 1 & $16(53.3 \%)$ & $33(53.2 \%)$ & 1.000 \\
\hline 2 & $12(40.0 \%)$ & $26(41.9 \%)$ & 1.000 \\
\hline 3 & $0(0 \%)$ & $2(3.2 \%)$ & 1.000 \\
\hline 4 & $2(6.7 \%)$ & $1(1.6 \%)$ & 0.247 \\
\hline pT(3+4) vspT(1+2) & $2(6.7 \%)$ & $3(4.8 \%)$ & 0.660 \\
\hline Regional metastasis, N1 & $8(26.6 \%)$ & $14(22.6 \%)$ & 0.795 \\
\hline Remote metastasis, M1 & $0(0.0 \%)$ & $0(0.0 \%)$ & 1.000 \\
\hline Intra thyroid spread & $17(73.9 \%)$ & $45(84.9)$ & 0.335 \\
\hline Extrathyroidal invasion & $7(23.3 \%)$ & $20(32.3 \%)$ & 0.468 \\
\hline Tumor capsule & $10(40.0 \%)$ & $11(19.6 \%)$ & 0.062 \\
\hline Multifocal growth & $2(8.3 \%)$ & $0(0 \%)$ & 0.094 \\
\hline Vascular invasion & $6(21.4 \%)$ & $1(1.7 \%)$ & 0.004 \\
\hline Dominant structural component & & & $9.200 \mathrm{E}-06$ \\
\hline papillary & $13(43.3 \%)$ & $55(88.7 \%)$ & $7.990 \mathrm{E}-06$ \\
\hline follicular & $11(36.7 \%)$ & $6(9.7 \%)$ & 0.003 \\
\hline solid & $6(20.0 \%)$ & $1(1.6 \%)$ & 0.004 \\
\hline Morphological structures present: \\
papillary & $19(63.3 \%)$ & $60(97.8 \%)$ & $4.872 \mathrm{E}-05$ \\
\hline follicular & $19(63.3 \%)$ & $32(51.6 \%)$ & 0.372 \\
\hline solid & $10(33.3 \%)$ & $7(11.3 \%)$ & 0.020 \\
\hline trabecular & $2(6.7 \%)$ & $14(22.6 \%)$ & 0.079 \\
\hline columnar and tall-cellular & $0(0 \%)$ & $3(4.8 \%)$ & 0.548 \\
\hline Wartin-like & $0(0 \%)$ & $4(6.5 \%)$ & 0.300 \\
\hline hobnail & $0(0 \%)$ & $2(3.2 \%)$ & 1.000 \\
\hline Focal oxyphilic cell metaplasia & $2(6.7 \%)$ & $19(30.6 \%)$ & 0.015 \\
\hline $\begin{array}{l}\text { Concomitant thyroid pathology: } \\
\text { nodal }\end{array}$ & $0(0 \%)$ & $9(17.6 \%)$ & 0.050 \\
\hline thyroiditis & $18(75.0 \%)$ & $35(68.6 \%)$ & 0.768 \\
\hline
\end{tabular}

No relationship between the mutant BRAF the sex was found $(p=0.330)$, which is generally in line with most studies of consecutive PTC series.

High statistical significance was found for the age at the time of surgery: patients with BRAF+ tumors (50.2 \pm 14.2 years) were significantly older than those with wild type BRAF (BRAF-, $36.7 \pm 12.9$ years) PTCs, $p=7.352 \times 10-5$. Similar relationship has been found in many studies; it is consistent with the notion that mutant BRAF+ is usually detected in older patients and is relatively rare in children and adolescents with PTC [12].

A more detailed investigation of the relationship of mutant BRAF with patientsage using $\mathrm{ROC}$ analysis confirmed the statistical significance of the correlation. Area under curve (AUC), shown in Figure 2, was 0.756, which exceeds the generally accepted level of minimal predictability $(0.700)$. The optimal cut-off threshold was 46.6 years.

Additional evidence of the connection of the frequency of mutant BRAF to the age was obtained using a linear trend analysis. Age subgroups were formed according to the 2015 WHO recommendation for adults, which classifies the age of $25-44$ as young, 44- 
60 - medium, 60-75 aged, 75-90 - senile, and 90+ years [13]. In our study, there were no patients older than 90 years, and in the subgroup of 75-90 years there were only two females aged 77 and 82; they were assigned to a group of $60+$ years. Six patients younger than 25 years (age at the time of operation 14-23 years) were classified as $<44$ years. The rates of detection of mutant BRAF in the age subgroups formed by the above method are shown in Table 2.

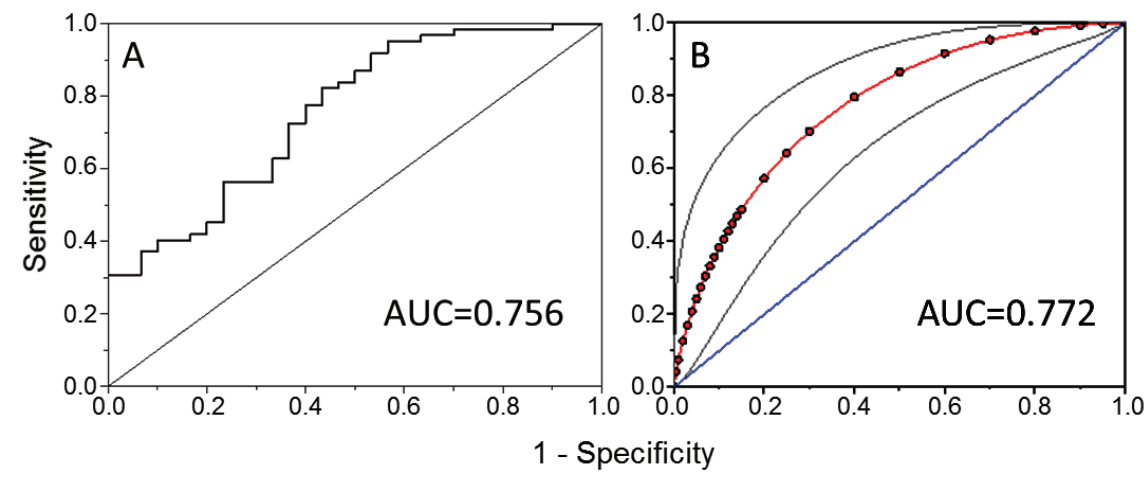

Fig. 2. ROC-analysis of the association of the mutant BRAF frequency with the patient's age: A - empirical ROC-curve; B - fitted ROC-curve (red line).

Grey lines show the $95 \%$ confidence interval boundaries. AUC areaundercurve
Kazakhstan, there was no correlation between the mutant BRAF with clinical and pathological characteristics. No associations with the pT category $(p=0.544)$, nodal disease $(p=0.795)$, intrathyroid spread $(p=0.335)$, extrathyroidal invasion $(p=0.468)$, tumor capsule $(p=0.062)$ and multifocality $(p=0.094)$ were detected. The only significant difference between the BRAF+ and BRAF- tumors was a lower incidence of vascular invasion in the former group (1.7\% versus $21.4 \%, p=0.004)$, which does not imply a higher aggressiveness of BRAF+ PTC.

In contrast, our analysis of the relationship of the mutant BRAF with morphological characteristics revealed of statistically significant associations. The strongest was the correlations with the papillary structural component. About $90 \%$ of tumors with the dominant papillary architectonics were BRAF+. The frequency of mutant BRAF was significantly decreasing in the papillary $>>$ follicular $>$ solid sequence $(p=9,200 E-06)$. We also noted that among 3 tumors with columnar and tall-cell features, mutant BRAF was detected in all $3(100 \%)$ cases. These results are in good agreement with the data

Table 2

Sex and age incidence of mutant BRAF presented in many papers [15].

Statistically significant association of mutant BRAF was also detected for the presence of oxyphilic cell changes (30.6\% vs. $6.7 \%, p=0.015)$ and a higher incidence of concomitant thyroid nodular pathology $(17.6 \%$ vs. $0 \%, p=0.05)$. The clinical significance of these correlations has yet to be established.

The relationships of a number of clinical and morphological characteristics of PTC with the presence of the mutant BRAF was further assessed by multivariate logistic regression analysis (Table 3 ). With the overall high statistical significance of the optimal model $(p=8,173 E-8)$, the older age $(O R=1,087(1,008-1,174)$, $p=0,031)$ and the presence of the dominant papillary structural component $(\mathrm{OR}=66,719(7,437-598,570)$, $\mathrm{p}=1.752 \mathrm{E}-04)$ independently correlated with BRAF+ tumor status. Also independent, butnegative was the relationship with the mutant BRAF for the tumor capsule $(O R=0.015(0.001-0.261), p=0.004)$ and concomitant thyroiditis $(\mathrm{OR}=0.115(0.016-0.848), \quad \mathrm{p}=0.034)$. Similar data were obtained in an earlier work [16], which showed that thyroiditis is relatively less frequent in - the BRAF mutant PTC.

Table 3

Multivariate model of the mutant BRAF association with the clinical and morphological parameters of PTC Breslow-Day test).

The sizes of BRAF+ and BRAF- tumors did not differ significantly either the continuous size scale $(p=0.758)$ or subgroup analysis $(p=0.065)$. The only difference was the lower frequency of mutant BRAF among tumors measuring from 1 to $2 \mathrm{~cm}(25.8 \%$ vs. $50.0 \%, p=0.033)$. In general, the data demonstrate that the association of the mutant BRAF with tumor size is not seen in the Kazakh population.

A number of studies have shown the relationship of the mutant BRAF to the higher pT category, clinical stage and PTC aggressiveness, such as the presence of regional metastasis and extrathyroidal invasion [14]. At the same time, a considerable number of investigations did not reveal such correlations. Our results rather coincide with the latter works. In the series of the PTC from

\begin{tabular}{|l|c|c|}
\hline \multicolumn{1}{|c|}{ Parameters } & OR $(95 \% \mathrm{CI})$ & $\mathrm{p}$ \\
\hline $\begin{array}{l}\text { Age at the time } \\
\text { of surgery }\end{array}$ & $1.087(1.008-1.174)$ & 0.031 \\
\hline $\begin{array}{l}\text { Dominant papillary } \\
\text { structural component }\end{array}$ & $\begin{array}{c}66.719 \\
(7.437-598.570)\end{array}$ & $1.752 \mathrm{E}-04$ \\
\hline Tumor capsule & $0.015(0.001-0.261)$ & 0.004 \\
\hline $\begin{array}{l}\text { Concomitant } \\
\text { thyroiditis }\end{array}$ & $0.115(0.016-0.848)$ & 0.034 \\
\hline Intrathyroid spread & $0.074(0.005-1.162)$ & 0.064 \\
\hline Vascular invasion & $0.039(0.001-1.076)$ & 0.055 \\
\hline $\begin{array}{l}\text { Focal oxy philic cell } \\
\text { metaplasia }\end{array}$ & $\begin{array}{c}8.273 \\
(0.586-116.795)\end{array}$ & 0.118 \\
\hline
\end{tabular}


The following parameters were included in the full model: sex, age at the time of surgery, maximum tumor size, tumor capsule, dominant structural component (papillary or other), pT category, pN category, intrathyroidspread, extrathyroidal invasion, vascular invasion, focal oxyphilic cell metaplasia, concomitant nodal disease and concomitant thyroiditis. Backward stepwise optimization of the model was performed.

In view of the high prevalence of the mutant BRAF in the Kazakh population, an attempt was made to assess the feasibility of detecting a mutation in clinical specimens. For this purpose, DNA from fine needle biopsy material was used, which was analyzed by ddPCR.

In the course of our pilot study, specimens with cytological findings corresponding to TBSRTC categories were collected as follows: category VI (malignant, 2 cases, $V$ (suspicious for malignancy, 1 case), IV (follicular neoplasm or suspicious for a follicular neoplasm, 1 case) and II (benign) - 2 samples, but with worrisome signs on ultrasound).

The results of the analysis are shown in Figure 3. Both 2 samples of category $\mathrm{VI}$ and 1 sample of category $\mathrm{V}$ were positive for the mutation of the BRAF gene. The sample of category IV was also positive. Somewhat unexpectedly, among the 2 «worrisome» samples of category II, 2 both were positive. One patient with the cytological category $\mathrm{VI}$ «malignancy» had been operated by the time of this work preparation, and the diagnosis of PTC was confirmed pathomorphologically.

These results show the potential usefulness of molecular analysis for clinical purposes, especially in cases that require further refining of preoperative diagnosis. Larger clinical series is needed to determine the significance and efficacy of molecular analysis of the mutant BRAF. Since BRAF ${ }^{\mathrm{V} 600 \mathrm{E}}$ is almost always heterozygous. The wild-type BRAF signal should be observed in all samples regardless of the presence of mutant BRAF. It also serves as an indicator of successful PCR (samples IV-1 and -K). The difference in the number of dotsbetween the mutant and wild-type BRAF (the latter is usually larger) may be due to the admixtures of DNA from non-target cells (e. g. Iymphocytes and stromal cells) that contain only wild-type BRAF. The smaller intensity of signals in some samples (VI-1 and II-2) can be explained by the presence of contaminates(principally. from the blood) that inhibit PTC; the inhibitory effect is

systemic and is observedfor both mutant and wild type BRAF.

Conclusions. A study in the consecutive patients with PTC from Kazakhstan showed a relatively high incidence of mutant BRAF $(67.4 \%)$, which generally corresponds to the incidence of BRAF ${ }^{\mathrm{V} 600 \mathrm{E}}$ PTC in other countries, including Asian.

We provide evidence for the independent association between mutant BRAF frequency and the older age of patients, the papillary structure of the tumor, the lower probability of the presence of a tumor capsule and concomitant thyroiditis. The relationship between mutant BRAF and clinical and morphological parameters of tumor aggressiveness were not found. The high potential usefulness of the detection of $\mathrm{BRAF}^{\mathrm{V} 600 \mathrm{E}}$ in the fine needle aspiration biopsy material was demonstrated. Based on the correlation of the mutation frequency with age, it can be especially recommended for patients older than 46 years, if necessary, to clarify the preoperative diagnosis.

Further research directionsin PTC patients from Kazakhstan should include the evaluation of the efficacy of molecular analysis in a prospective series, and the determination of the prognostic potential of BRAF ${ }^{\mathrm{V} 600 \mathrm{E}}$ using follow-up data.

\section{Disclosures:}

The authors declare that they have no conflict of interest.

Acknowledgements. Authors are grateful Drs Rogounovitch T. I., Matsuse M., Yamashita S., Abrosimov A. Yh., Saenko V. A. and other workers of Department of Radiation Molecular Epidemiology Atomic Bomb Disease Institute (Nagasaki, Japan) that were involved in IHC and PCR are much acknowledged.

\section{References}

1. La Vecchia C., Malvezzi M., Bosetti C., Garavello W., Bertuccio P. [et al.] Thyroid cancer mortality and incidence: a global overview. Int. J. Cancer. 2015;136:2187-2195. https://doi.org/10.1002/ijc.29251

2. Grubbs E. G., Rich T. A., Li G., Sturgis E. M., Younes M. N. [et al.] Recent advances in thyroid cancer. Curr. Probl. Surg. 2008;45(3):156-250. https://doi.org/10.1067/j.cpsurg.2007.12.010
3. Jemal A., Siegel R. Xu J. Ward E. Cancer Statistics 2010. CA Cancer J. Clin. 2010;60:277-300. https://doi.org/10.3322/caac.20073

4. Nishant A. R., Akbani B., Arman A., Adrian A., Harindra A. [et al.] Cancer Genome Atlas Research Network. Integrated Genomic Characterization of Papillary Thyroid Carcinoma. Cell. 2014;159:676-690. https://doi.org/10.1016/j.cell.2014.09.050 
5. Carol Li., Kathleen C., Lee E. B., SchneiderM. A., Zeiger A. BRAF V600E mutation and Its Association with Clinicopathological Features of Papillary Thyroid Cancer: a meta-analysis. J. Clin. Endocrinol. Metab. 2012;97:45594570. https://doi.org/10.1210/jc.2012-2104

6. Jeong D., Jeong Y., Park J. H., Han S. W., Kim S. Y. [et al.] BRAF (V600E) mutation analysis in papillary thyroid carcinomas by peptide nucleic acid clamp real-time PCR. Ann. Surg. Oncol. 2013;20:759-66.

https://doi.org/10.1245/s10434-012-2494-0

7. Basolo F., Torregrossa L., Giannini R., Miccoli M., Lupi C. [et al.] Correlation between the BRAF V600E mutation and tumor invasiveness in papillary thyroid carcinomas smaller than 20 millimeters: analysis of 1060 cases. J. Clin. Endocrinol. Metab. 2010;95:4197-205. https://doi.org/10.1210/jc.2010-0337

8. Vasiliev E. V., Rumiantsev P. O., Saenko V. A., Ilyin A. A., Polyakova E. Yu. [et al.] Molecular analysis of structural disorders of the genome of papillary thyroid carcinoma. Molecular biology. 2004;38(4):642-653.

9. Yasuhiro I., Hiroshi Y., Minoru K., Kaoru K., Akihiro M. [et al.] BRAF ${ }^{\mathrm{V} 600 \mathrm{E}}$ Mutation Analysis in Papillary Thyroid Carcinoma: Is it Useful for all Patients? World Journal of Surgery. 2014;38:679-687. https://doi.org/10.1007/s00268-013-2223-2

10. De Lellis R. A., Lloyd R., Heitz Ph. WHO Classification of tumors, Vol. 8, Pathology and genetics of tumors of the endocrine organs, 3rd ed. IARCPress, Lyon. 2004.

11. Yamashita S., Saenko V. A. Mechanisms of Disease: molecular genetics of childhood thyroid cancers. Nat. Clin. Pract. Endocrinol. Metab. 2007;3(5):422-429. https://doi.org/10.1038/ncpendmet0499

12. Ahmad O. B., Boschi-Pinto C., Lopez A. D., Murray $C h$. J. L., Lozano $R$. [et al.] Age standardization of rates: a new WHO standard. GPE Discussion Paper Series: №31. EIP/GPE/EBD World Health Organization 2001. http://www.who.int/healthinfo/paper31.pdf

13. Xing M. BRAF mutation in papillary thyroid cancer: pathogenic role, molecular bases, and clinical implications. Endocr Rev. 2007;28(7):742-62. https://doi.org/10.1210/er.2007-0007

14. Xing M. BRAF mutation in thyroid cancer. Endocr. Relat. Cancer. 2005;12(2):245-62. https://doi.org/10.1677/erc.1.0978

15. Sargent R., Li Volsi V., Murphy J., Mantha G., Hunt J. L. BRAF mutation is unusual in chronic lymphocytic thyroiditis-associated papillary thyroid carcinomas and absent in non-neoplastic nuclear atypia of thyroiditis. Endocr. Pathol. 2006;17(3):235-41.

16. Cibas E. S., Ali S. Z. The 2017 Bethesda System for Reporting Thyroid Cytopathology. Thyroid. 2017;27(11):13411346. https://doi.org/10.1089/thy.2017.0500

\title{
About authors:
}

Tlegenov Askar Shindalievich, PhD medicine, Assistant at the Department of Endocrinology; tel.: +77759018381; e-mail: tash741980@mail.ru

Abylaiuly Zhangentkhan, DMSc, Professor; tel.: +77057009729; e-mail: s.bolshakova@inbox.ru

Adilbay Dauren Galymovich, Deputy Director for Science; Head of onco-surgical department of head and neck tumors; tel.: +7 7015113432; e-mail: dr.dauren@gmail.com

Yeleubaeva Shanar Bolatovna, Cytomorphologist of the pathomorphological laboratory; tel.:+77051339279; e-mail: Zhanara66@gmail.com Adilbayev Galym Basenovich, DMSc, Professor of separation of head and neck tumors; tel.: +77013116013; e-mail: g.adilbayev@gmail.com Satbaeva Elvira Bolatovna, CMSc, Head of pathomorphological laboratory; tel.: +77078083810; e-mail: somaka@mail.ru

\section{POSITIVE IMPACT OF ULTRASOUND IN MANAGEMENT OF ACUTE APPENDICITIS IN CHILDREN}

\author{
Raffaele A., Romano P., Guazzotti M., Vatta F., Cavaiuolo S., \\ Brunero M., Avolio L., Parigi G. B.
}

Fondazione IRCCS Policlinico San Matteo and University of Pavia, Italy

\section{ПОАОЖИТЕАЬНЫЙ ЭФФЕКТ ПРИМЕНЕНИЯ УАЬТРАСОНОГРАФИИ ПРИ АЕЧЕНИИ ОСТРОГО АППЕНАИЦИТА У АЕТЕЙ}

\author{
А. Рафффаэле, П. Романо, М. Гуазотти, Ф. Ватта, С. Кавайольо, \\ М. Брунеро, А. Авольо, Ж. Б. ПариАжи
}

\section{Институт научных исслеАований, мечения и ухоАа ФонАазиони Сан-Маттео и Университет Павиа, Италия}

In the sturdy was to quantify the impact of ultrasound (US) in the diagnosis and general management of acute appendicitis in children. Retrospective review of children assessed for acute abdominal pain in the Emergency Department (ED). Out of 327 patients, $145(44.4 \%)$ were examined also with US. A total of 154 patients underwent surgery, of which $67(43.6 \%)$ after US scan and $87(56.4 \%)$ with no US. Differences in surgical timing and procedure, histologic findings and length of stay in 